\title{
Macro and Micromorphological Studies on Seven Species of Heliotropium L. (Boraginaceae Juss.) in South West of Saudi Arabia
}

\author{
Wael Taha Kasem 1,2 \\ ${ }^{1}$ Botany and Microbiology Department, Faculty of Science, Al-Azhar University, Cairo, Egypt \\ ${ }^{2}$ Biology Department, Faculty of Science, Jazan University, Jazan, KSA \\ Email: wael kasm@yahoo.com
}

Received 9 April 2015; accepted 6 June 2015; published 9 June 2015

Copyright (C) 2015 by author and Scientific Research Publishing Inc.

This work is licensed under the Creative Commons Attribution International License (CC BY). http://creativecommons.org/licenses/by/4.0/

\section{(c) (i) Open Access}

\begin{abstract}
Genus Heliotropium L. (Heliotropiaceae) in south west of Saudi Arabia has been studied; seven species of $\boldsymbol{H}$. arbainense Fresen, $\boldsymbol{H}$. Iongiflorum (D.C.) Jauber \& Spach, $\boldsymbol{H}$. petrocarpum Hockst \& Steud, $H$. strigosium Willd, $H$. zeylanicum Lam., $H$. jizanense Al-Turki and $H$. lasiocarpum Fisch were collected, recognized, typed and nomenclatured. The most valuable characters were those of macro and distinct micromorphological data such as stomata, hairs, pollen grains and stem anatomy. Light microscopy has been used in these studies. From the obtained results, trichomes and pollen grains data in addition to stem anatomy indicated good taxonomic tools to differentiate between species of this genus. Different traditional measurements were strikingly also helpful for the discrimination of species. $H$. longiflorum was characterized by distinctive data such as prominent anatomical information, $\mathrm{P} / \mathrm{E}(1.8 \mu \mathrm{m})$ in addition to presence of spindle hair which in turn can be separated as a taxonomic level. Also, the results revealed a complete affinity between the two species of $\boldsymbol{H}$. jizanense and $\boldsymbol{H}$. lasiocarpum. An artificial key is provided for the differentiation between the studied species.
\end{abstract}

\section{Keywords}

Heliotropium L., Leaf Venation, Stomata, Trichomes, Pollen Grains, Stem Anatomy

\section{Introduction}

Heliotropium L. related to Heliotropiaceae Schrad., which was included in Boraginaceae Juss. It considered pa- 
raphyletic taxon [1] [2]. Now Heliotropiaceae deals as a separate family [3]. Heliotropium is selected for its importance and strong resemblances on the morphological characters. The infrageneric classification of Heliotropium into sections has been a debatable matter. Recently, Olwey [4] mentioned this genus divided into Section Heliotropium, Section Orthostachys, Section Pleurolasia, Section Pseudocoelomae, Section Pterotropium, Section Ruditotheca and Section Zeylanica. There are 10 species of genus Heliotropium distributed in Jazan of Saudi Arabia [5] [6]. Distribution and forms of trichomes are important qualities to be used to differentiate between the different genera and species of plant [7]. Leaf epidermal characters are useful in systematic phylogeny of several plant taxa and can be employed as useful taxonomic characters in segregating the major groups of plants [8]-[10]. [11] investigated leaf anatomy and distribution of foliar trichrome of four Heliotropium species which have been investigated in Saudi Arabia. On the other hand, [12] carried out a comparison between the anatomical leaves and stems structure of five species of genus Heliotropium in Sudan. [13] reported the occurrence of tricolpate pollen grain in $H$. vellosum and $H$. indicum. Genus Heliotropium is characterized by its striking similarity on morphological characters, so this study aims to evaluate the systematic relationships of their similarity and dissimilarity compared to the modern findings of taxonomic relationships of species within the genus.

\section{Materials and Methods}

Fresh samples of the seven species of the genus Heliotropium were collected from different localities of Jazan. The plant specimens were identified according to [5] [6] Ten sample epidermal strips were removed from lower surface of the leaves were; these were fixed in $20 \%$ glycerine. The slides were examined under the light microscope at $40 \times$. Various anatomical features, such as number and type of stomata, length and width of stomata, trichomes form and types were studied. The size of stomata and hair were recorded with the help of a calibrated eyepiece. The stomatal index (S.I.) was calculated using the formula adopted from [14] that is:

$$
\mathrm{SI}=\mathrm{S} / \mathrm{S}+\mathrm{E} \times 100
$$

where $S$ is the number of stomata per unit of area, and $E$ the number of epidermal cells in the same area. Pollen grains from fresh plants were collected on a slide and acetolyzed according to the method of [13]. Acetolyzed pollen grains were photographed by light microscope. For anatomical studies, stem cross sections were done using freshly-collected material or material fixed in ethanol, this material was cut free hand or in a semi rotative microtome to make semi-permanent and permanent slides for the microscopic slides, carried out according to the usual Johansen's methods [15].

\section{Results and Discussion}

\subsection{Leaf and Inflorescence Morphology}

Some distinctive characters such as inflorescence length, leaf shape and venation have been studied and summarized in Table 1.

According to the terminology of [16] [17], there are two types of venation found: Hyphodromous and Brochidodromous.

\subsection{Stomatal Behavior}

The qualitative and quantitative leaf epidermal features of the taxa and their frequency of stomatal indexes are presented in Table 2 and Figure 1. Amphistomatic stomata are common in all the studied taxa. Their ranunculus distributed on the adaxial and the abaxial surface of the leaves. The stomatal length, width and frequency also varied. The maximum stomatal length and pore size were observed in $H$. petrocarpum $(19 \mathrm{~mm})$ followed by $H$. strigosium being $17 \mathrm{~mm}$ and the minimum stomata length was found in $H$. zeylanicum $(7 \mathrm{~mm})$ followed by $H$. longiflorium $(9 \mathrm{~mm})$. Three types of stomata were recognized; anomocytic type is common in the tree species: $H$. petrocarpum, $H$. strigosium and $H$. zeylanicum. Paracytic type was found only in $H$. arbainense. Anisocytic types were noticed in $H$. longiflorum and $H$. lasiocarpum. Stomatal index differed between the taxa, where the highest value of $44.87 \%$ was calculated for $H$. jizanense while the lowest index (28.57\%) was noticed in $H$. longiflorum.

\subsection{Epidermal Trichromes}

Unicellular epidermal trichromes have been watched on both the surface of stem and leaves. Also, glandular 


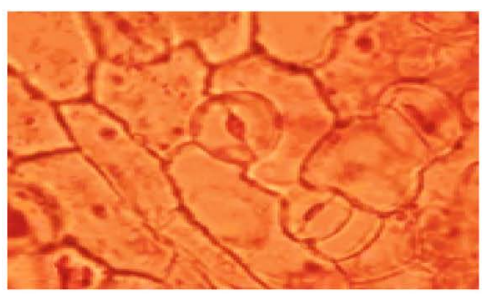

(a)

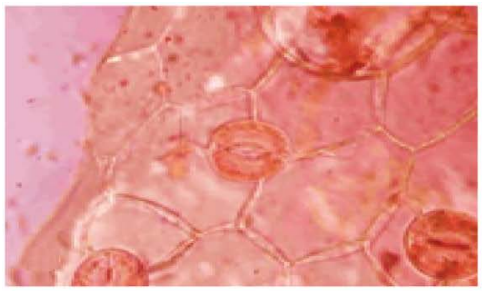

(d)

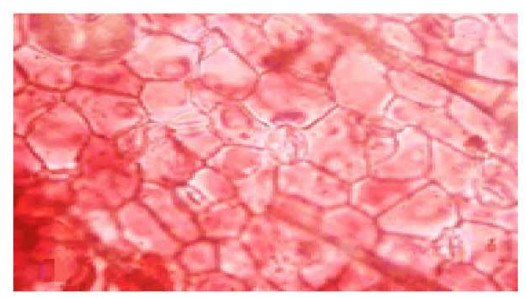

(b)

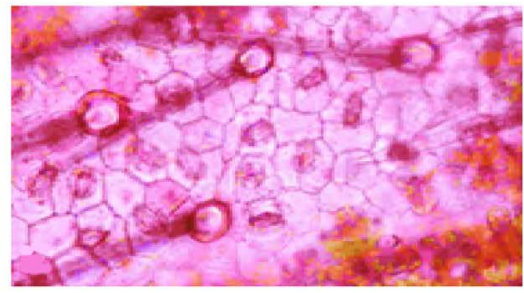

(e)

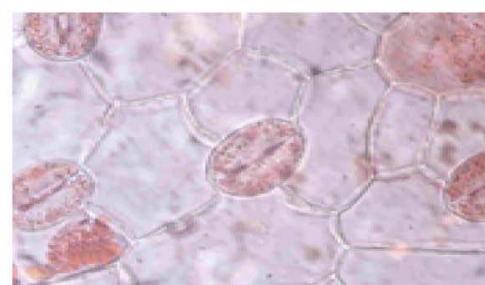

(c)

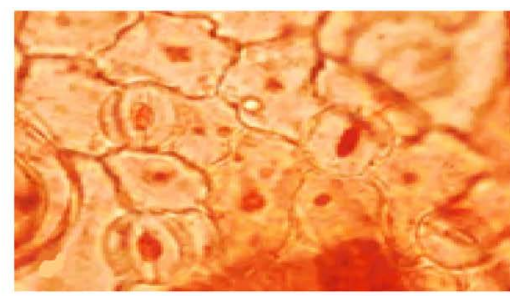

(f)

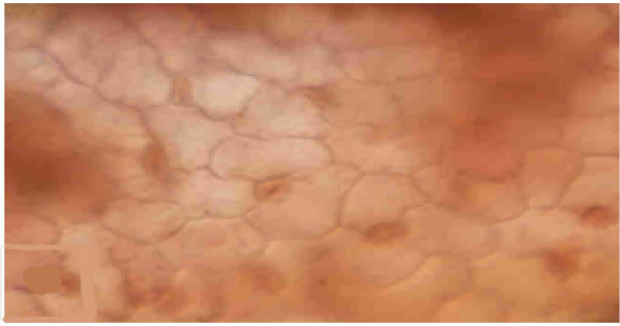

(g)

Figure 1. Photographical images of epidermal cells showing the stomata types ( $\mathrm{x}=400)$. (a) $H$. arbainense (anisocytic); (b) $H$. longiflorium (paracytic); (c) H. petrocarpum (anomocytic); (d) H. strigosium (anomocytic); (e) H. zeylanicum (anomocytic); (f) H. jizanense (anisocytic); (g) H. lasiocarpum (anisocytic).

Table 1. Leaf and inflorescence measurements between the studied species.

\begin{tabular}{cccccccc}
\hline \multirow{2}{*}{ No. } & \multirow{2}{*}{ Species } & \multirow{2}{*}{ Data } & \multicolumn{3}{c}{ leaf measurements } & \multicolumn{3}{c}{ Inflorescence measurements } \\
\cline { 4 - 8 } & & Length $\mathbf{( c m )}$ & Width $(\mathbf{c m})$ & Leaf form & Length & Color \\
\hline $\mathbf{1}$ & H. arbainense & Brochidodromous & $2.0-3.0$ & $2.0-3.0$ & ovate & $0.8-1.0$ & Yellow \\
$\mathbf{2}$ & H. longiflorum & Hyphodromous & $2.5-4.5$ & $1.0-2.5$ & linear & $2.0-4.0$ & White \\
$\mathbf{3}$ & H. petrocarpum & Hyphodromous & $2.0-4.0$ & $2.0-3.2$ & lanceolate & $1.0-2.0$ & White \\
$\mathbf{4}$ & H. strigosium & Hyphodromous & $1.9-2.9$ & $0.8-1.2$ & linear & $1.0-2.0$ & White \\
$\mathbf{5}$ & H. zeylanicum & Hyphodromous & $3.0-4.0$ & $0.5-2.5$ & lanceolate & $4.0-6.0$ & White \\
$\mathbf{6}$ & H. jizanense & Hyphodromous & $1.5-2.6$ & $0.8-1.1$ & elliptic & $2.0-3.0$ & White \\
$\mathbf{7}$ & H. lasiocarpum & Brochidodromous & $2.0-2.1$ & $0.3-0.5$ & ovate & $1.0-2.0$ & White \\
\hline
\end{tabular}

Table 2. Stomata measurements and stomata indices for the species.

\begin{tabular}{|c|c|c|c|c|c|c|c|}
\hline Species & Epidermal No & Stomata No. & Stomata types & Subsidiary cells & $\begin{array}{c}\text { Stomata } \\
\text { length (mm) }\end{array}$ & $\begin{array}{c}\text { Stomata } \\
\text { width (mm) }\end{array}$ & $\begin{array}{c}\text { Stomata } \\
\text { index (\%) }\end{array}$ \\
\hline H. arbainense & 20 & 12 & Paracytic & Teteacytic & 10 & 5 & 28.57 \\
\hline H. longiflorum & 35 & 14 & Anisocytic & Actinocytic & 9 & 6 & 36.00 \\
\hline H. petrocarpum & 32 & 18 & Anomocytic & Teteacytic & 19 & 17 & 41.66 \\
\hline H. strigosium & 32 & 22 & Anomocytic & Teteacytic & 17 & 13 & 40.70 \\
\hline H. zeylanicum & 28 & 20 & Anomocytic & Tetracytic & 7 & 5 & 37,50 \\
\hline H. jizanense & 43 & 35 & Anisocytic & Teteacytic & 13 & 11 & 39.09 \\
\hline H. lasiocarpum & 53 & 34 & Anisocytic & Teteacytic & 15 & 12 & 44.87 \\
\hline
\end{tabular}


hairs were found in all the seven studied taxa. Basal hair form and vestibule differed between the taxa where hollow appeared in $H$. arbainense, $H$. peterocarpum and $H$. jizanense. Spindle hair form was found only in $H$. longicarpum; density, type, basal cell and their walls are presented in Table 3 and photographed in Figure 2.

Densely hairy with filled basal cells was found in $H$. lasiocarpum, $H$. strigosum and $H$. zeylanicum hairs with rough walls.

\subsection{Pollen Grain Characters}

Pollen grains types form and different measurements are recorded in Table 4. Tricolpate pollen grains types were noticed in all the species (Figure 3). Oval form was found in H. longiflorum. Circular was found in

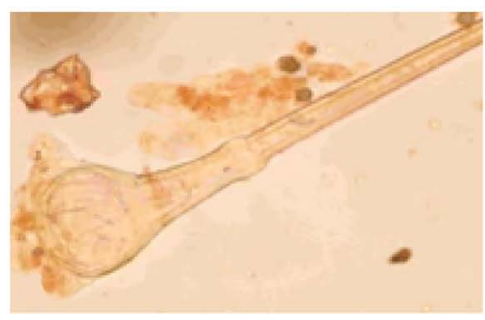

(a)

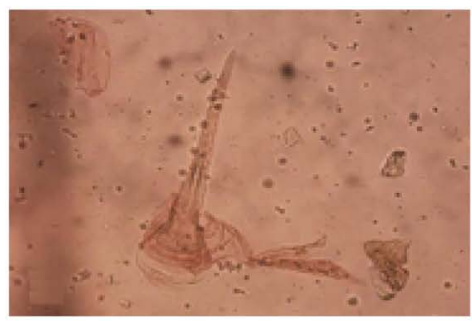

(d)

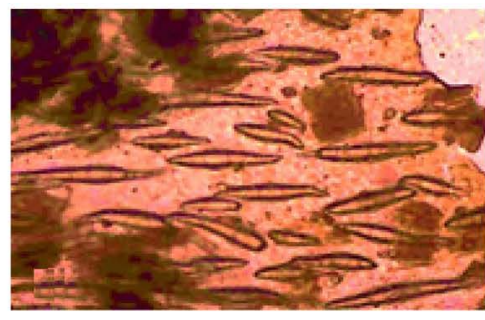

(b)

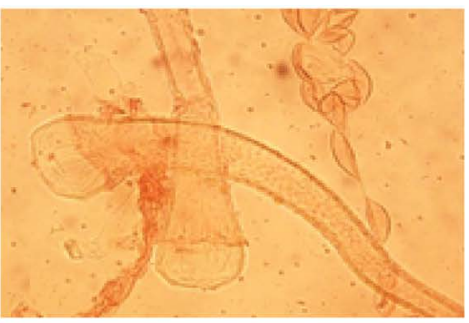

(e)

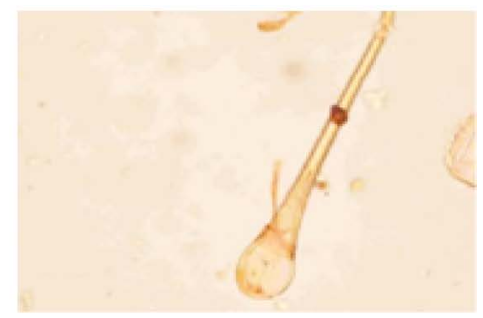

(c)

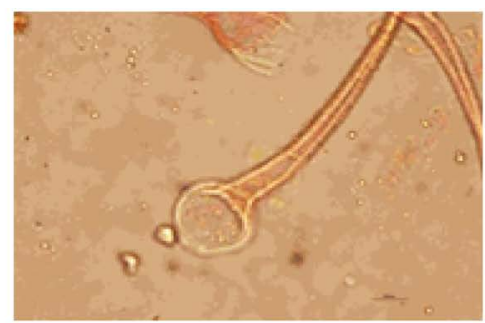

(f)

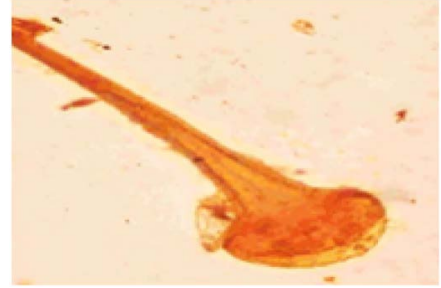

(g)

Figure 2. Light microscopic images $(\mathrm{X}=100)$ showing hollow and filled vestibule basal hair in the studied species. (a) $H$. arbainense; (b) H. longiflorium (paracytic); (c) H. petrocarpum; (d) H. strigosium; (e) H. zeylanicum; (f) H. jizanense; (g) H. lasiocarpum.

Table 3. Hair leaves measurements for the seven studied species.

\begin{tabular}{ccccc}
\hline \multicolumn{1}{c}{ Data } & Hair density & Hair wall & Hair vestibule & Basal form \\
\hline Species & Dense & Smooth & Hollow & Oval \\
H. arbainense & Dense & Rough & Absent & Rounded \\
H. longiflorum & Low & Smooth & Hollow & Oval \\
H. petrocarpum & Dense & Rough & Filled & Oval \\
H. strigosium & Low & Rough & Filled & Globose \\
H. zeylanicum & Low & Smooth & Hollow & Circular \\
H. jizanense & Low & Rough & Filled & Absent \\
H. lasiocarpum & & & & \\
\hline
\end{tabular}




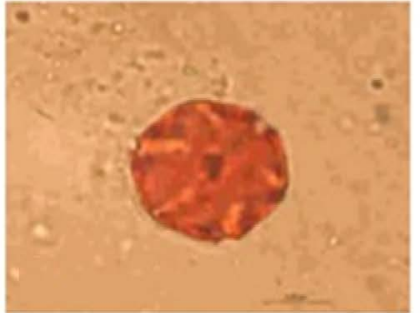

(a)

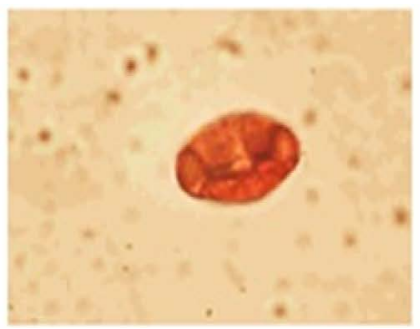

(d)

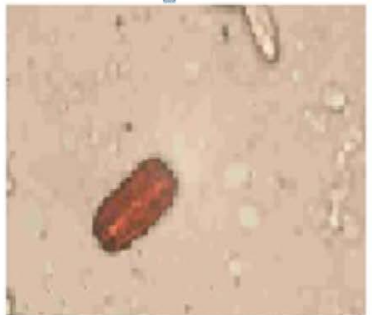

(b)

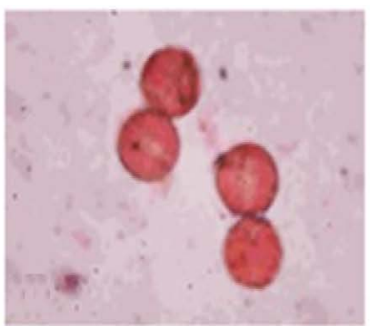

(e)

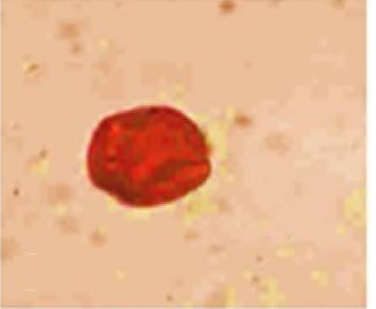

(c)

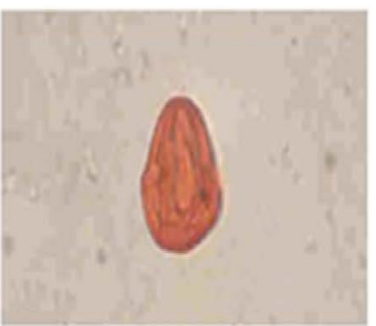

(f)

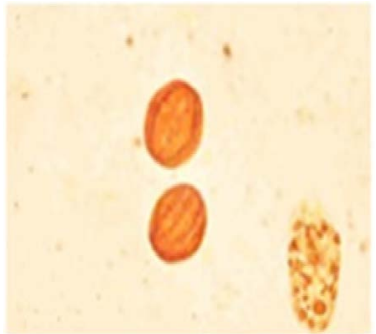

(g)

Figure 3. Equatorial view by light microscopic images $(\mathrm{X}=1000)$ of oval form in $H$. longiflorum, rectangula in $H$. arbainense and $H$. petrocarpum, elliptical in $H$. strigosium, rounded in $H$. zeylanicum and triangular in $H$. jizanense

Table 4. Pollen grain measurements for the seven studied species.

\begin{tabular}{|c|c|c|c|c|c|}
\hline Species Data & $\begin{array}{l}\text { Pollen length } \\
(\mu \mathrm{m})\end{array}$ & $\begin{array}{l}\text { Pollen width } \\
\qquad(\mu \mathrm{m})\end{array}$ & $\begin{array}{l}\text { Pollen apertures } \\
(\mu \mathrm{m})\end{array}$ & $\begin{array}{l}\text { P/E ratio } \\
(\mu \mathrm{m})\end{array}$ & Pollen form \\
\hline H. arbainense & 28 & 20 & 0.8 & 0.70 & Circular \\
\hline H. longiflorum & 20 & 11 & 0.7 & 1.81 & Circular \\
\hline H. petrocarpum & 25 & 22 & 0.5 & 1.13 & Circular \\
\hline H. strigosium & 27 & 16 & 0.3 & 1.68 & Elliptical \\
\hline H. zeylanicum & 32 & 28 & 0.4 & 1.14 & Rounded \\
\hline H. jizanense & 41 & 35 & 0.9 & 1.17 & Triangular \\
\hline H. Iasiocarpum & 38 & 31 & 0.8 & 1.22 & Oval \\
\hline
\end{tabular}

$H$. arbainense and $H$. petrocarpum. Elliptical form was noticed in $H$. strigosium. Rounded form was recorded in $H$. zeylanicum, and also triangular was noticed in $H$. jizanense. The pollen length and aperture size also varied between the taxa. The maximum pollen length and width $(\mathrm{P} / \mathrm{E})$ of $1.81 \mu \mathrm{m}$ were recorded in $H$. longiflorum followed by 1.68 found in $H$. strigosium. The lowest P/E was noticed in $H$. arbainense $(0.70 \mu \mathrm{m})$.

\subsection{Stem Anatomical Data}

Stem anatomical characters and their measurements between the studied species are recorded in Table 5 and stem photographs are listed in Figure 4. Epidermis in all species consists in a single layer. All taxa except $H$. pterocarpum have two layers of cubical or rounded cells covering with trichromes. Hairs and other epidermal outgrowths have been noticed in all species; the hypodermis consists of elongated chlorenchyma cells in $H$. 


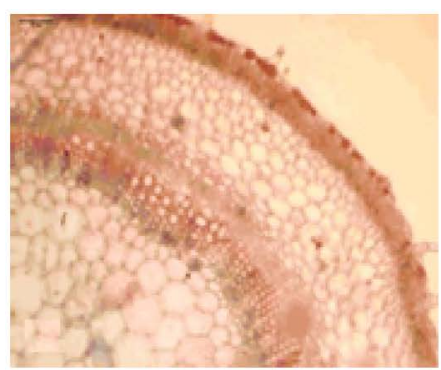

(a)

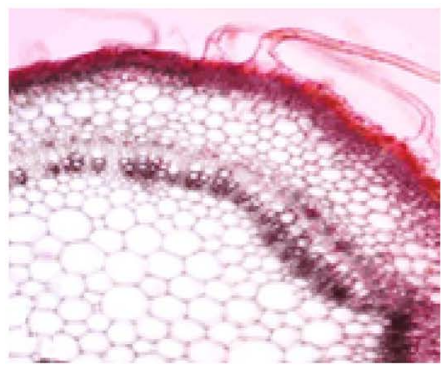

(d)

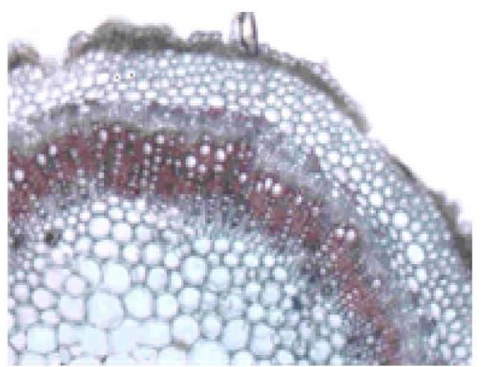

(b)

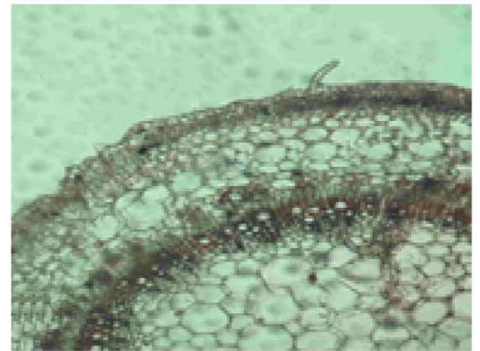

(e)

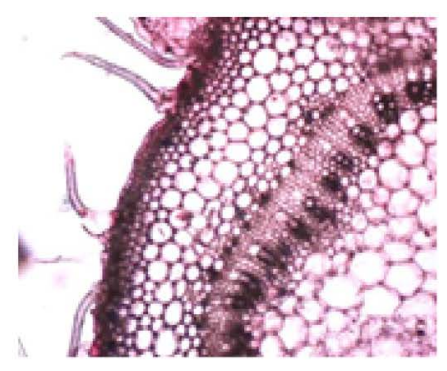

(c)

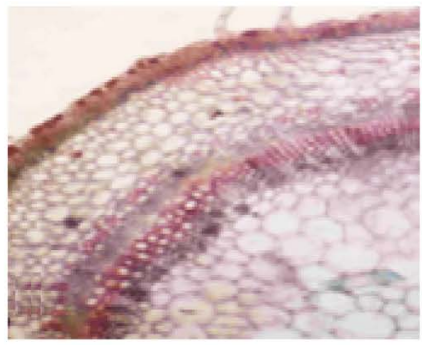

(f)

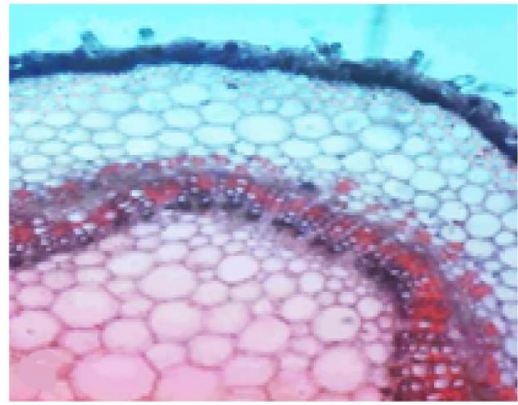

(g)

Figure 4. Light microscopic micrograph $(\mathrm{X}=100)$. (a) H. arbainense; (b) H. longiflorium; (c) H. petrocarpum; (d) H. strigosium; (e) H. zeylanicum; (f) H. jizanense; (g) H. lasiocarpum.

Table 5. Anatomical measurements between the studied species.

\begin{tabular}{|c|c|c|c|c|c|c|}
\hline Species & Epidermal layers & Hypoderm layers & Cortex cells & Vessels clusters & Wood porous & Pith cells \\
\hline H. arbainense & one & One, elongated & Angular & Two groups & Diffuse & Rounded \\
\hline H. longiflorum & one & Two, elongated & Normal & Three groups & Diffuse & Rounded \\
\hline H. petrocarpum & two & One, elongated & Normal & two groups & Diffuse & Rounded \\
\hline H. strigosium & one & Two, elongated & Lacunar & Three groups & Un-diffuse & oval \\
\hline H. zeylanicum & one & Three, rounded & Normal & Three groups & Diffuse & Rounded \\
\hline H. jizanense & two & One, elongated & Angular & Three group & Diffuse & oval \\
\hline H. lasiocarpum & one & One, elongated & circular & Three group & Diffuse & rounded \\
\hline
\end{tabular}

arbainense, $H$. pterocarpum and $H$. zeylanicum. Two layers of chlorenchyma cells were observed in $H$. longiflorum and $H$. strigosium. Three layers of parenchyma cells were found only in $H$. jizanense. The cortex was found in angular with 4 - 5 layers of collenchyma cells which were present in $H$. arbainense and $H$. jizanense. 5 - 6 layers of lacunar collenchyma cells were found in $H$. strigosium. A normal collenchyma cell was found in $H$. longiflorum, $H$. petrocarpum and $H$. zeylanicum. Vascular strands in all the taxa studied are separated by paren- 
chymatous cells which are smaller in size than cortex or pith. Vessels are scattered and clustered into two groups in H. arbainense and H. petrocarpum or three groups in $H$. longiflorum, $H$. strigosium, H. zeylanicum and $H$. jizanense. In the old stem sections continuous ring of fascicular and iterfascicular cambium has been observed in all the studied species. Primary phloem appears as a dark staining mass in $H$. longiflorium and H. strigosium. Wood vessels are scattered and clustered into two groups in $H$. arbainense and $H$. petrocarpum or three groups in $H$. longiflorum, $H$. zeylanicum and $H$. jizanense. In general, leaf venation varied between the species, brochidodromous noticed in $H$. arbainense and $H$. lasiocarpum while the remainders have hyphodromous type. Such results are similar to report of [3]. It is obvious that, the stomatal index varied between the studied species in turn in accordance with the results of [18]. Apart from hairs, emergences and glandular hairs have been noted previously by different authors. Glandular hairs with multicellular stalk have been observed in all the seven species. Hairs vary from species to other which in turn indicated at significant taxonomic data; basal hair form appeared hollow in $H$. arbainense, $H$. peterocarpum and $H$. jizanense. Spindle shape was found only in $H$. longiflorum with rough hair wall which differed from the previous studies. Also, pollen grains indicated good taxonomic data which differed in form and pollen apertures. Such results are in agreement with [19]. Also, the pollen length and apertures size also varied between the taxa studied. $H$. longiflorum has distinct anatomical data which support data obtaining pollen grains in which colporate pollen aperture is $\mathrm{P} / \mathrm{E}(1.8 \mu \mathrm{m})$ in addition to presence of hair spindle form. The hypodermis showed variation and accordingly $H$. zeylanicum was separated from the other studied species having 2 layers of chlorenchyma cells whereas the remainders species have 1 - 2 layers of parenchyma cells. Vessel forms, number and wood porous differed between the taxa. Wood porous found in all taxa except $H$. strogosium has unporous xylem form. Such results differed with results of [12]. On the other hand, $H$. longiflorum is characterized by distinctive data which in turn can be separated as a taxonomic level; the following key shows the possibility of using both the previous characters for identification of the studied Heliotropium species:

\begin{tabular}{lll}
\hline 1a. & Flowers bracteates, weakly scorpoid form, with spindle hairs & 5. H. longiflorum \\
1b. & Flowers bracteates, rarely scorpioid cymose, with elliptical pollen grains & H. strigosum \\
1c. & Flowers unbracteate & 2 \\
2a. & Calyx lobes confined, heavy hairs, $4-5 \mathrm{~mm}$ & H. pterocarpum \\
2b. & Calyx lobes free, have little hairs or not hairy & 3 \\
3a. & Plants annual, nutlets glabrous & 5 \\
3b. & Plants perennial, nutlets hairy & H. lasiocarpum \\
4a. & Nutlets not winged; stigma abruptly narrowed, filiform & H. jizanense \\
4b. & Nutlets shortly winged; stigma conical & 1 \\
5a. & Corolla green; inflorescence up to 15 - 20 cm long & 6 \\
5b. & Corolla yellow or white, inflorescence less than 12 cm long & H. arbainense \\
6a. & Stigma sessile; flowers white, wood vessels clustered in two groups & H. zeylanicum \\
6b. & Stigma narrowly elongate; flowers yellow, wood vessels clustered in three groups & \\
\hline
\end{tabular}

\section{References}

[1] Chase, M.W. (1993) Phylogenetics of Seed Plants: An Analysis of Nucleotid Sequences from the Plastid Gene rbcL. Annals of the Missouri Botanical Garden, 80, 528-580. http://dx.doi.org/10.2307/2399846

[2] Ferugson, D.M. (1999) Phylogenetic Analysis and Relationship in Hydro-Phyllaceae Based on ndhF Sequence Data. Systematic Botany, 23, 253-268. http://dx.doi.org/10.2307/2419504

[3] Diane, N., Further, H. and Hilger, H. (2002) A Systematic Analysis of Heliotropium, Tournefortia, and Allied Taxa of the Heliotropiaceae (Boraginales) Based on ITS1 Sequences and Morphological Data. American Journal of Botany, 89, 287-295. http://dx.doi.org/10.3732/ajb.89.2.287

[4] Olwey, A. (2014) Transcript of Biosystematics Studies of Genus Heliotropium L. (Boraginaceae). MSc Thesis, De- 
partment of Botany \& Microbiology, Faculty of Science, Assiut University, Assiut.

[5] Alfarhan, A., Al-Turky, T. and Basahy, A. (2005) Flora of Jazan Region. Final Report, Vol. 1-2, Supported by King Abdulaziz City for Science and Technology, 545.

[6] Masrahi, Y.S. (2012) A Brief Illustrate to Wild Plants in Jazan Region. King Fahad Library, Jeddaha, 302.

[7] Metcalf, C.R. and Chalk, L. (1950) Anatomy of the Dicotyledons Vol. II. Clarendon Press, Oxford, 1067-1074.

[8] Mbagwu, F.N., Nwachukwu, C.U. and Okon, O. (2007) Comparative Leaf Epidermal Studies on Solanum macrocarpon and Solanum nigrum. Nature and Science, 5, 1-6.

[9] Ayodele, A.E. and Zhou, Z.K. (2008) Scanning Electron Microscopy of Leaves in the West African Polygonaceae. Nigerian Journal of Botany, 21, 252-265.

[10] Albert, S. and Sharma, B. (2013) Comparative Foliar Micromorphological Studies of Some Bauhinia (Legiminoseae) Species. Turkish Journal of Botany, 37, 278-281.

[11] Mona, A. and Bukhary, N. (2013) Anatomical Study of Four Species of Heliotropium L. (Boraginaceae) from Saudi Arabia. African Journal of Plant Science, 7, 35-42. http://dx.doi.org/10.5897/AJPS12.136

[12] Hoyam, O. and Maha, A. (2012) Leaf and Stem Anatomy of Five Species from the Genus Heliotropium L. (Boraginaceae) in Sudan. Journal of Chemical and Pharmaceutical Research, 4, 4575-4581.

[13] Erdtman, G. (1952) Pollen Morphology and Plant Taxonomy-Angiosperms. Almqvist and Wiksell, Stockholm, 539 p.

[14] Salisbury, E.J. (1927) On the Cause and Ecological Significance of Stomatal Frequency with Special Reference to the Woodland Flora. Philosophical Transactions of the Royal Society of London: Biological Sciences, 216, 1-65. http://dx.doi.org/10.1098/rstb.1928.0001

[15] Johansen, O.A. (1940) Plant Microtechnique. McGraw-Hill Book Co., Inc., New York.

[16] Hickey, L.J. and Wolf, J.A. (1975) The Basis of Angiosperm Phylogeny Vegetative Morphology. Annals of the Missouri Botanical Garden, 62, 538-589. http://dx.doi.org/10.2307/2395267

[17] Ash, A., Ellis, B., Hickey, K., Johnson, P. and Wing, S. (1999) Manual of Leaf Architecture-Morphological Description and Categorization of Dicotyledonous and Net-Veined Monocotyledonous Angiosperms. Smithsonian an Institution, Washington DC.

[18] Dasti, A.A., Bokhari, T.Z., Malik, S.A. and Akhtar, R. (2003) Epidermal Morphology in Some Members of Family Boraginaceae in Baluchistan. Asian Journal of Plant Sciences, 42, 42-47.

[19] Qureshi, S.A. (1985) Studies on the Pollen Morphology of the Genus Heliotropium L. Pakistan Journal of Botany, 17, 107-114. 